\title{
Regulation of taurine transport at the blood- placental barrier by calcium ion, PKC activator and oxidative stress conditions
}

\author{
Na-Young Lee, Young-Sook Kang ${ }^{*}$ \\ From $17^{\text {th }}$ International Meeting of Taurine \\ Fort Lauderdale, FL, USA. 14-19 December 2009
}

\begin{abstract}
Background: In the present study, we investigated the changes of uptake and efflux transport of taurine under various stress conditions using rat conditionally immortalized syncytiotrophoblast cell line (TR-TBT cells), as in vitro blood-placental barrier (BPB) model.

Methods: The transport of taurine in TR-TBT cells were characterized by cellular uptake study using radiolabeled taurine. The efflux of taurine was measured from the amount of radiolabeled taurine remaining in the cells after the uptake of radiolabeled taurine for 60 min.

Results: Taurine uptake was significantly decreased by phosphorylation of protein kinase C (PKC) activator in TRTBT cells. Also, calcium ion $\left(\mathrm{Ca}^{2+}\right)$ was involved in taurine transport in TR-TBT cells. Taurine uptake was inhibited and efflux was enhanced under calcium free conditions in the cells. In addition, oxidative stress induced the change of taurine transport in TR-TBT cells, but the changes were different depending on the types of oxidative stress inducing agents. Tumor necrosis factor- $\alpha$ (TNF- $\alpha$ ), lipopolysaccharide (LPS) and diethyl maleate (DEM) significantly increased taurine uptake, but $\mathrm{H}_{2} \mathrm{O}_{2}$ and nitric oxide (NO) donor decreased taurine uptake in the cells. Taurine efflux was down-regulated by TNF- $\alpha$ in TR-TBT cells.

Conclusion: Taurine transport in TR-TBT cells were regulated diversely at extracellular $\mathrm{Ca}^{2+}$ level, PKC activator and oxidative stress conditions. It suggested that variable stresses affected the taurine supplies from maternal blood to fetus and taurine level of fetus.
\end{abstract}

\section{Introduction}

Taurine, one of the essential nutrients, exists in high concentration in most tissues, where it shows various physiological functions such as including conjugation with bile acids, anti-oxidation, detoxification, osmoregulation, membrane stabilization and modulation of intracellular calcium level [1-4]. Also, taurine plays an important role in fetal development because taurine deficiency during pregnancy is associated with growth retardation, retinal degeneration and dysfunction of the central nervous system (CNS) $[5,6]$. In general, it was

\footnotetext{
* Correspondence: yskang@sookmyung.ac.kr

College of Pharmacy and Research Institute of Pharmaceutical Science,

Sookmyung Women's University, Seoul, 140-742, Republic of Korea

Full list of author information is available at the end of the article
}

known that taurine can be supplied to most of human tissues by diet or biosynthesis in human body. However, although taurine is a pivotal amino acid at fetal and neonatal stages, the fetus has low capacities to synthesize taurine due to deficiency of enzyme, cysteine sulfinate decarboxylase [2]. Thus, taurine has to be supplied to the fetus from the maternal circulating blood via placenta.

The placenta regulates transport of nutrients and exchange of gases between maternal and fetal blood, and the blood-placenta barrier (BPB), which is composed of syncytiotrophoblast cells, has a key role in these functions [7]. It already has been reported that human placental syncytiotrophoblast possesses an active high-affinity transport system for taurine, the taurine 
transporter (TauT) $[8,9]$. TauT is dependent on sodium and chloride ion and is regulated by protein kinase $\mathrm{C}$ (PKC), glucose, hypertonicity and cytokine in various cells and organs such as brain, retina, intestinal cell and hepatic cell [2].

In the present study, we focused on the effect of oxidative stress on taurine transport in placenta. It was known that taurine plays a role as an antioxidant in the human body. Accordingly, transport activity of taurine may be also changed at the $\mathrm{BPB}$ under the pathophysiological conditions induced by oxidative stress, and this change could intensely affect the protective effect of taurine by influencing taurine concentration in the fetus. In the recent report, it showed that the level of taurine in the fetus at intrauterine growth restriction (IUGR) was low [10], NO level was also high in IUGR pregnancies [11]. It suggests a mutual relation between oxidative stress and taurine transport. However, the regulation of taurine transport at the BPB under oxidative stress remains uncertain at the present time. Thus, it is necessary to investigate the effect of oxidative stress on taurine transport in placenta. Oxidative stress in the cells is induced by increased oxidant generation, decreasing oxidant protection and failure of repairing oxidative damage. A reactive oxygen species (ROS) is generated in vivo by aerobic respiration, metabolism of xenobiotic compounds and inflammation induced by phagocytosis process [12]. Therefore, we evaluated the regulation of taurine transport under various conditions inducing oxidative stress such as pro-inflammatory cytokine, tumor necrosis factor- $\alpha$ (TNF- $\alpha$ ); bacterial endotoxin, lipopolysaccharide (LPS); compound inducing a depletion of antioxidant such as glutathione, diethyl maleate (DEM); a ROS compound, hydrogen peroxide $\left(\mathrm{H}_{2} \mathrm{O}_{2}\right)$; nitric oxide (NO) donor, 3-morpholinosyndomine (SIN-1).

Kitano et al. established a conditionally immortalized rat syncytiotrophoblast cell line, TR-TBT cells, from pregnant transgenic rat placenta at gestational day 18 [13]. TR-TBT $18 \mathrm{~d}-1$ and $18 \mathrm{~d}-2$ were originated from the syncytiotrophoblast I (maternal side) and II (fetal side), respectively, because rat syncytiotrophoblast consists of two layers while that of human is composed with one layer. TR-TBT cells is a good model for the analysis of the placental transport of nutrients $[13,14]$. We have carried out this study using TR-TBT cells as an in vitro BPB model.

\section{Materials and methods Materials}

Radiolabeled $\left[{ }^{3} \mathrm{H}\right]$ taurine (SA $20.1 \mathrm{Ci} / \mathrm{mmol}$ ) was obtained from NEN Life Science Products Inc. (Boston, MA). Tumor necrosis factor- $\alpha$ (TNF- $\alpha$ ), lipopolysaccharide
(LPS), 3-morpholinosyndomine (SIN-1), phorbol 12-myristate 13-acetate (PMA), nifedipine, nimodipine, verapamil, nickel chloride $\left(\mathrm{NiCl}_{2}\right)$ and cadmium chloride $\left(\mathrm{CdCl}_{2}\right)$ were purchased from Sigma Chemical (St. Louis, MO). Diethyl maleate (DEM) and hydrogen peroxide $\left(\mathrm{H}_{2} \mathrm{O}_{2}\right)$ was obtained from Aldrich chemical Co. (St. Louis, MO) and Junsei chemical Co. (Tokyo, Japan), respectively.

\section{Cell culture}

The TR-TBT cells were cultured with Dulbecco's modified Eagle's medium (Invitrogen, San Diego, CA), supplemented with $10 \%$ fetal bovine serum, $100 \mathrm{U} / \mathrm{ml}$ penicillin, and $100 \mu \mathrm{g} / \mathrm{ml}$ streptomycin (Invitrogen, San Diego, CA) at $33^{\circ} \mathrm{C}$ in a humidified atmosphere of $5 \%$ $\mathrm{CO}_{2} /$ air. On rat tail collagen type I-coated 24 well culture plates (IWAKI, Tokyo, Japan) initial seeding was done at $1 \times 10^{5}$ cells/well for the uptake study. After incubation for 3 days at $33^{\circ} \mathrm{C}$, the cultures became confluent. Then the cells were incubated at $37^{\circ} \mathrm{C}$ for a further 3 days.

\section{Functional studies}

The $\left[{ }^{3} \mathrm{H}\right]$ taurine uptake was performed according to the previous report [15]. TR-TBT cells were washed three times with $1 \mathrm{ml}$ extracellular fluid (ECF) buffer consisting of $122 \mathrm{mM} \mathrm{NaCl}, 25 \mathrm{mM} \mathrm{NaHCO}, 3 \mathrm{mM} \mathrm{KCl}, 1.4$ $\mathrm{mM} \mathrm{CaCl} 2,1.2 \mathrm{mM} \mathrm{MgSO}_{4}, 0.4 \mathrm{mM} \mathrm{K}_{2} \mathrm{HPO}_{4}, 10 \mathrm{mM}$ D-glucose and $10 \mathrm{mM}$ Hepes (pH 7.4) at $37^{\circ} \mathrm{C}$. Uptake was initiated by applying $200 \mu \mathrm{L}$ containing $\left[{ }^{3} \mathrm{H}\right]$ taurine $(28 \mathrm{nM})$ at $37^{\circ} \mathrm{C}$. Under a $\mathrm{Ca}^{2+}$ free condition, $\mathrm{Ca}^{2+}$ was replaced with $\mathrm{Mg}^{2+} \cdot\left[{ }^{3} \mathrm{H}\right] \mathrm{T}$ aurine uptake was stopped by removing the isotope ECF buffer and washing the cells with ice ECF buffer three times. To investigate the effect of phosphorylation of PKC on taurine uptake in TRTBT cells, the cells was pre-incubated for $30 \mathrm{~min}$ in the presence of a PKC activator, PMA $(1 \mu \mathrm{M})$. After that, $\left[{ }^{3} \mathrm{H}\right]$ taurine uptake study was performed as described above. To investigate the change of taurine uptake under the oxidative stress condition, the TR-TBT cells were pretreated with $20 \mathrm{ng} / \mathrm{mL}$ TNF- $\alpha, 10 \mathrm{ng} / \mathrm{mL}$ LPS, $100 \mu \mathrm{M}$ DEM, $2 \mathrm{mM} \mathrm{H} \mathrm{H}_{2} \mathrm{O}_{2}$ or $1 \mathrm{mM} \mathrm{SIN-1}$ for $3,6,9$, 12 and $24 \mathrm{~h}$, and the uptake study was performed as described above. The cells were then solubilized by incubation overnight in $750 \mu \mathrm{l}$ of $1 \mathrm{~N} \mathrm{NaOH}$ at RT. An aliquot $(50 \mu \mathrm{l})$ was taken for quantification of cellular protein using a DC protein assay kit (Bio-Rad, Hercules, CA) with bovine serum albumin as a standard. The remaining solution $(500 \mu \mathrm{l})$ was mixed with $5 \mathrm{ml}$ of scintillation cocktail (Hionic-fluor; Packard, Meriden, CT) for measurement of radioactivity in a liquid scintillation counter (LS6500; Beckman, Fullerton, CA).

The efflux of $\left[{ }^{3} \mathrm{H}\right]$ taurine by TR-TBT cells was determined by incubating the cells for $60 \mathrm{~min}$ at $37^{\circ} \mathrm{C}$ with $\left[{ }^{3} \mathrm{H}\right]$ taurine dissolved in ECF buffer. The medium was 
then removed, and the cells were washed with ice-cold ECF buffer. The incubation medium alone or $\mathrm{Ca}^{2+}$ free medium was added for desired times. After appropriate time periods, the incubation medium was removed and the amount of $\left[{ }^{3} \mathrm{H}\right]$ taurine remained in the cells was measured. To induce oxidative stress in the cells, the TR-TBT cells were pretreated with $20 \mathrm{ng} / \mathrm{mL}$ TNF- $\alpha$, $10 \mathrm{ng} / \mathrm{mL}$ LPS and $100 \mu \mathrm{M}$ DEM for $9 \mathrm{hrs}, 9 \mathrm{hrs}$ and $12 \mathrm{hrs}$, respectively, and the efflux study was performed as described above.

\section{Data analysis}

All data are given as mean \pm SEM values. Statistical analyses were carried out by one-way ANOVA with Dunnett's post-hoc test and $\mathrm{p}<0.05$ was considered statistically significant.

\section{Results}

Effect of protein kinase $C$ (PKC) on the taurine uptake in TR-TBT cells

Taurine transport was regulated by phosphorylation of PKC in TR-TBT cells. As exposed to PKC activator, PMA $(1 \mu \mathrm{M}),\left[{ }^{3} \mathrm{H}\right]$ taurine uptake was significantly decreased in TR-TBT cells (Fig. 1).

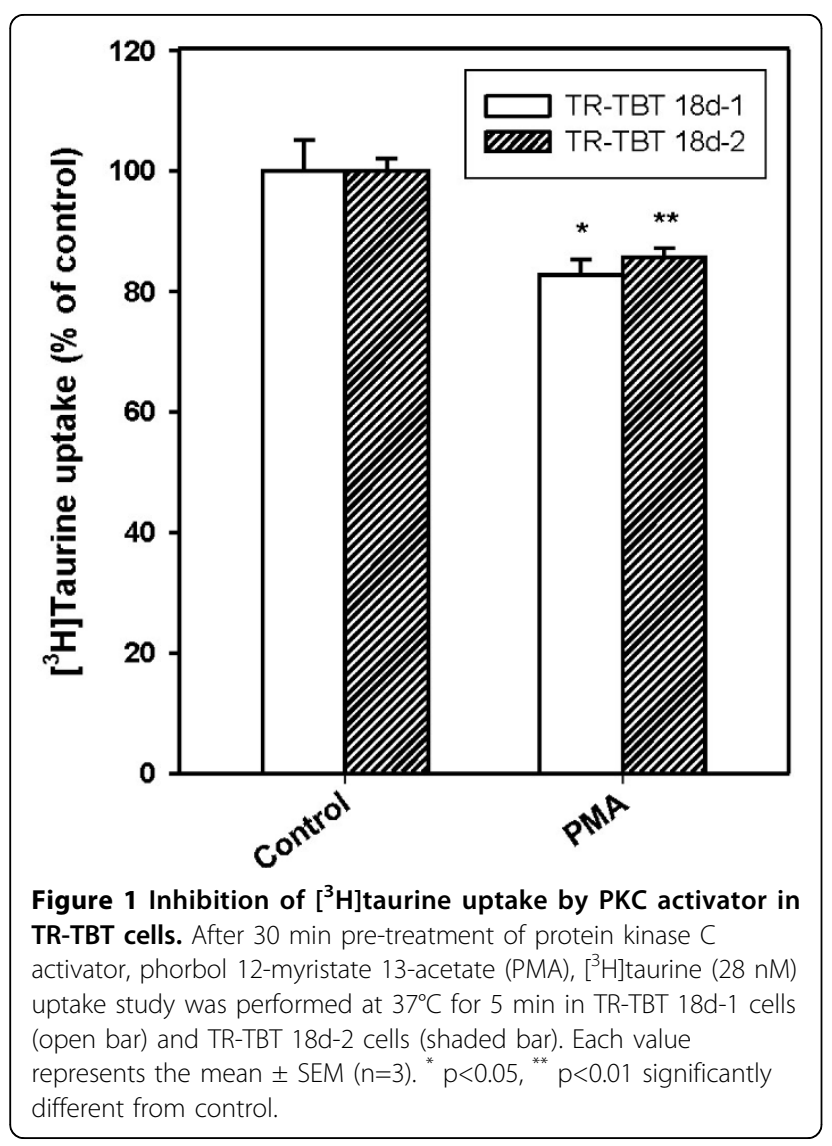

Effect of $\mathrm{Ca}^{2+}$ and calcium channel blockers on the taurine transport in TR-TBT cells

We investigated the effect of $\mathrm{Ca}^{2+}$ on taurine transport in TR-TBT cells by removal of $\mathrm{Ca}^{2+}$ from ECF buffer or addition of various calcium channel blockers in ECF buffer. Under $\mathrm{Ca}^{2+}$ free conditions, $\left[{ }^{3} \mathrm{H}\right]$ taurine uptake was significantly reduced in TR-TBT cells (Fig. 2). Various calcium channel blockers such as $0.3 \mathrm{mM}$ verapamil, $2 \mathrm{mM}$ nifedipine, $1 \mathrm{mM} \mathrm{NiCl}$ and $0.3 \mathrm{mM} \mathrm{CdCl}_{2}$ induced a significant decrease of the $\left[{ }^{3} \mathrm{H}\right]$ taurine uptake (Fig. 2). But, $\left[{ }^{3} \mathrm{H}\right]$ taurine uptake was not changed in the presence of nimodipine in the cells (Fig. 2). In the presence of $2.8 \mathrm{mM}$ (2-folds) $\mathrm{Ca}^{2+}$, the $\left[{ }^{3} \mathrm{H}\right]$ taurine uptake had no change in TR-TBT $18 \mathrm{~d}-1$ cells, and was increased slightly in TR-TBT $18 \mathrm{~d}-2$ cells. The efflux of $\left[{ }^{3} \mathrm{H}\right]$ taurine was increased significantly in the cells under $\mathrm{Ca}^{2+}$ depletion condition (Table 1).

\section{Effect of oxidative stress on the taurine transport in TR- TBT cells}

We investigated a change of the taurine uptake and efflux under oxidative stress conditions in TR-TBT cells. To induce various oxidative stress conditions, the cells were incubated in TNF- $\alpha(20 \mathrm{ng} / \mathrm{mL})$, LPS $(10 \mathrm{ng} / \mathrm{mL})$, DEM $(100 \mu \mathrm{M}), \mathrm{H}_{2} \mathrm{O}_{2}(2 \mathrm{mM})$ and SIN-1 $(1 \mathrm{mM})$ for 3, $6,9,12$ and 24 hrs. $\left[{ }^{3} \mathrm{H}\right]$ Taurine uptake was significantly increased by pre-treatment with TNF- $\alpha(20 \mathrm{ng} / \mathrm{mL})$, LPS $(10 \mathrm{ng} / \mathrm{mL})$ and DEM $(100 \mu \mathrm{M})$ for $24 \mathrm{hrs}$ in the cells (Table 2). Whereas, as exposed to $2 \mathrm{mM} \mathrm{H}_{2} \mathrm{O}_{2}$ and

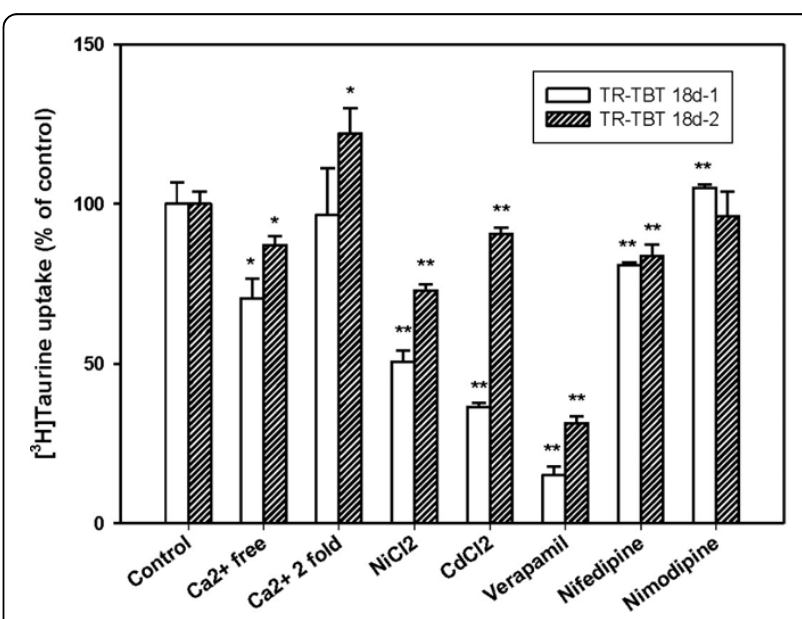

Figure 2 Effect of $\mathrm{Ca}^{2+}$ and calcium channel blockers on $\left[{ }^{3} \mathrm{H}\right]$ taurine uptake by TR-TBT cells. $\left[{ }^{3} \mathrm{H}\right]$ Taurine $(28 \mathrm{nM})$ uptake was performed at $37^{\circ} \mathrm{C}$ for $5 \mathrm{~min}$ in ECF buffer in the absence or the presence of $2.8 \mathrm{mM}$ calcium ion, $1 \mathrm{mM}$ nickel chloride, $0.3 \mathrm{mM}$ cadmium chloride, $0.3 \mathrm{mM}$ verapamil, $2 \mathrm{mM}$ nifedipine and $2 \mathrm{mM}$ nimodipine in TR-TBT 18d-1 cells (open bar) and TR-TBT 18d-2 cells (shaded bar). Under $\mathrm{Ca}^{2+}$ free condition, $\mathrm{Ca}^{2+}$ was replaced $\mathrm{Mg}^{2+}$. Each value represents the mean \pm SEM $(n=3-4) .{ }^{*} p<0.05,{ }^{* *} p<0.01$ significantly different control. 
Table 1 Effect of calcium ion on $\left[{ }^{3} \mathrm{H}\right]$ taurine efflux in TRTBT cells

\begin{tabular}{lcc}
\hline Condition & $\begin{array}{c}\text { Intracellular amount of }\left[^{3} \mathbf{H}\right] \text { taurine remained (\% of } \\
\text { time } \mathbf{0})\end{array}$ \\
\hline & TR-TBT 18d-1 & TR-TBT 18d-2 \\
\hline Control & $100 \pm 2$ & $100 \pm 3$ \\
$\mathrm{Ca}^{2+}$ free & $72.1 \pm 3.3^{* *}$ & $75.7 \pm 4.5^{* *}$
\end{tabular}

Cells were incubated for $60 \mathrm{~min}$ at $37^{\circ} \mathrm{C}$ with ECF buffer containing $\left[{ }^{3} \mathrm{H}\right]$ taurine $(28 \mathrm{nM})$. The cells were washed and then incubated with ECF buffer or $\mathrm{Ca}^{2+}$ free buffer for 30 min Under $\mathrm{Ca}^{2+}$ free condition, $\mathrm{Ca}^{2+}$ was replaced with $\mathrm{Mg}^{2+}$. Remaining of $\left[{ }^{3} \mathrm{H}\right]$ taurine in the cells was measured. Each value represents the mean \pm SEM $(n=3-4)$. ${ }^{* *} p<0.01$ significantly different from normal efflux.

$1 \mathrm{mM} \mathrm{SIN}-1$ for $24 \mathrm{hrs}$ in the cells, $\left[{ }^{3} \mathrm{H}\right]$ taurine uptake was significantly decreased (Table 2).

The effect of TNF- $\alpha$, LPS and DEM pre-treatment on $\left[{ }^{3} \mathrm{H}\right]$ taurine efflux was also examined in TR-TBT cells. Fig. 3 showed the effect of TNF- $\alpha$, LPS and DEM pretreatment on the $\left[{ }^{3} \mathrm{H}\right]$ taurine efflux for the designated time. LPS and DEM pre-treatment did not affect $\left[{ }^{3} \mathrm{H}\right]$ taurine efflux significantly, but TNF- $\alpha$ treatment inhibited $\left[{ }^{3} \mathrm{H}\right]$ taurine efflux significantly in the cells (Fig. 3).

\section{Discussion}

In the present study, we investigated the change of taurine transport via the placenta under various stress conditions using TR-TBT cells. It was reported that taurine transporter (TauT) existed in human placenta [8] and also the presence of TauT in TR-TBT cells was identified [14]. We also identified the characteristics of TauT which were previously known in various cells and organs such as brain, retina and intestinal cell [2] from the results (data not shown). The taurine uptake had time and sodium and chloride ion dependency and substrate specificity in TR-TBT cells. $\left[{ }^{3} \mathrm{H}\right]$ Taurine uptake was decreased significantly under extracellular calcium depletion (Fig. 2). The taurine uptake had calcium ion dependency as well as sodium and chloride ion, and it

Table 2 Effect of oxidative stress inducing agents on $\left[{ }^{3} \mathrm{H}\right]$ taurine uptake in TR-TBT cells

\begin{tabular}{ccc}
\hline Pretreatment & \multicolumn{2}{c}{$\left.{ }^{\mathbf{3}} \mathrm{H}\right]$ Taurine uptake (\% of control) } \\
\hline Compounds & TR-TBT 18d-1 & TR-TBT 18d-2 \\
\hline Control & $100 \pm 7$ & $100 \pm 14$ \\
$\mathrm{TNF}-\alpha 20 \mathrm{ng} / \mathrm{mL}$ & $139 \pm 11^{*}$ & $150 \pm 12^{* *}$ \\
$\mathrm{LPS} 10 \mathrm{ng} / \mathrm{mL}$ & $124 \pm 4^{* *}$ & $128 \pm 7^{*}$ \\
$\mathrm{DEM} 100 \mu \mathrm{M}$ & $137 \pm 16^{* *}$ & $154 \pm 11^{* *}$ \\
$\mathrm{H}_{2} \mathrm{O}_{2} 2 \mathrm{mM}$ & $85.2 \pm 1.8^{* *}$ & $79.8 \pm 3.2^{* *}$ \\
$\mathrm{SIN}-11 \mathrm{mM}$ & $66.8 \pm 2.2^{* *}$ & $84.2 \pm 3.8^{*}$ \\
\hline
\end{tabular}

Cells were treated with tumor necrosis factor- $\alpha$ (TNF- $\alpha, 20 \mathrm{ng} / \mathrm{mL}$ ), lipopolysaccharide (LPS, $10 \mathrm{ng} / \mathrm{mL})$, diethyl maleate (DEM, $100 \mu \mathrm{M})$, hydrogen peroxide $\left(\mathrm{H}_{2} \mathrm{O}_{2}, 2 \mathrm{mM}\right)$ and 3-morpholinosyndomine ( $\left.\mathrm{SIN}-1,1 \mathrm{mM}\right)$ for $24 \mathrm{hrs}$, respectively. $\left[{ }^{3} \mathrm{H}\right.$ ]Taurine $(28 \mathrm{nM})$ uptake was performed at $37^{\circ} \mathrm{C}$ for $5 \mathrm{~min}$. Each value represents the mean $\pm \operatorname{SEM}(n=3-4) .{ }^{*} p<0.05,{ }^{* *} p<0.01$ significantly different from the control.

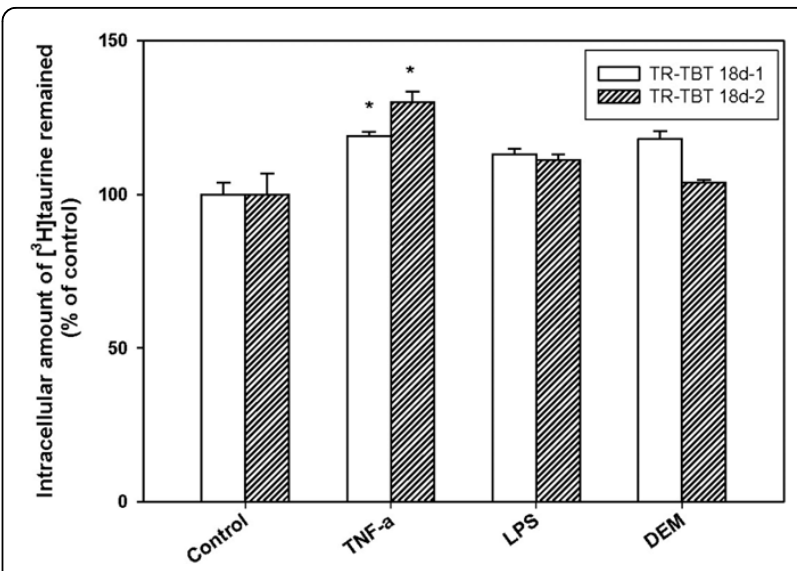

Figure 3 Effect of oxidative stress inducing agents on $\left[{ }^{3} \mathrm{H}\right]$ taurine efflux by TR-TBT cells. Cells were pre-treated with several stimulants for the specific time showed maximal taurine uptake, TNF- $\alpha(20 \mathrm{ng} / \mathrm{mL})$ for $9 \mathrm{hrs}$, LPS $(10 \mathrm{ng} / \mathrm{mL})$ for 9 hrs and DEM (100 $\mu \mathrm{M})$ for $12 \mathrm{hrs}$, respectively and then $\left[{ }^{3} \mathrm{H}\right]$ taurine efflux was examined in TR-TBT 18d-1 (open bar) cells and TR-TBT 18d-2 cells (shaded bar). Each value represents the mean $\pm \operatorname{SEM}(n=3) .{ }^{*} p<$ 0.05 , significantly different from control.

was sensitive to calcium depletion in extracellur fluid than calcium abundance (Fig. 2). In addition, the taurine efflux was evoked under calcium free condition about $20 \%$ over control (Table 1 ). These results suggested that an increase of taurine efflux might contribute to a decrease of taurine uptake at calcium free condition. Also, $\mathrm{Na}^{+}-\mathrm{Ca}^{2+}$ exchanger is associated with these effects of $\mathrm{Ca}^{2+}$ on taurine transport [4]. A change of $\mathrm{Ca}^{2+}$ concentration at intracellular or extracellular environment induced a change of $\mathrm{Na}^{+}$concentration, and it may affect taurine transport by the cells because taurine transporter is very sensitive to $\mathrm{Na}^{+}$concentration. Also, it was reported that $\mathrm{Ca}^{2+}$ free medium enhanced the taurine efflux in the rat striatum in vivo [17]. According to this study, the mechanism of an increase of taurine efflux by calcium depletion was considered that decreased calcium influx and increased nonspecific influx of $\mathrm{Na}^{+}$into the cells induced an increase of taurine efflux [17]. Therefore, the decrease of taurine uptake under calcium depletion may be related with the increase of taurine efflux through the change of concentration of $\mathrm{Na}^{+}$in the cells.

Taurine acts as an antioxidant, and has protection function when cell is damaged by oxidative stress [2]. This study showed that taurine uptake was increased under oxidative stress conditions for $24 \mathrm{hrs}$, TNF- $\alpha$, LPS and DEM, respectively pro-inflammatory cytokine, bacterial endotoxin and a compound inducing oxidative stress by depleting of glutathione levels (Table 2). It was reported that mRNA level of TauT and taurine uptake by the cells was increased in brain capillary endothelial 
cells [18], astrocytes [19] and intestinal cells [16] by pretreatment of TNF- $\alpha$. The TNF- $\alpha$ signal is known to activate nuclear factor $-\kappa \mathrm{B}(\mathrm{NF}-\kappa \mathrm{B})$ transcriptional activity by nuclear translocation [20]. Also, the NF- $\kappa \mathrm{B}$ binding site is found in the TauT promoter region [20]. Therefore, it suggested that the TNF- $\alpha-\mathrm{NF}-\kappa \mathrm{B}$ pathway could be associated in TauT up-regulation. DEM induced oxidative stress through the depletion of intracellular glutathione (GSH) [21] and up-regulated the cystine uptake in the organ [22]. Taurine is also sulfurcontaining amino acid like cystine, therefore, it seems that DEM may induce an increase of taurine uptake in TR-TBT cells. It was reported that LPS reduced taurine uptake significantly in macrophage cell lines and Caco2 cells [23-25], had no effect in conditionally immortalized brain microvascular endothelial cells [18]. In macrophage cell line, it was explained that LPS decreased taurine uptake might be via the action of nitric oxide [23]. In the present study, LPS increased taurine uptake slightly in TR-TBT cells, and it is contrary to previous results. It is known that LPS stimulates production of many kinds of cytokines such as TNF- $\alpha$. Therefore, it may be possible that taurine uptake was increased by TNF- $\alpha$ stimulated by LPS. Also, under hypertonic conditions, LPS activates taurine transport [24]. It is possible therefore to speculate that a switch controls the direction of LPS effect, but the complexity of the signaling pathways makes it very difficult [25]. The mechanism study of changes of taurine transport by LPS is needed to be further elucidated.

On the other hand, treatment of hydrogen peroxide induced reduction of taurine uptake (Table 2). Meng and colleagues showed that hydrogen peroxide elevated the phosphorylation of tyrosine residues via inhibition of tyrosine phosphatase [26]. Several of the serines, threonines and tyrosines in the intracellular domains of TauT are situated in motifs highly suitable as targets for protein kinases. In general, TauT is regulated by protein kinase C (PKC) phosphorylation of Ser-322, so activation of PKC inhibits taurine transport $[2,3]$. It was reported that there is possibility that a shift of TauT to a more tyrosine phosphorylated state in congruence with increased serine/threonine phosphorylation of Tau $\mathrm{T}$ reduces the active taurine uptake following exposure to hydrogen peroxide [27]. We also identified that taurine uptake was inhibited by activator of PKC, PMA in TR-TBT cells (Fig. 1). It has been known that PMA activates $\mathrm{Ca}^{2+}$ dependent and $\mathrm{Ca}^{2+}$ independent PKCs [28]. Accordingly, an increased phosphorylation of TauT could be involved in $\mathrm{H}_{2} \mathrm{O}_{2}$-induced reduction of taurine uptake in TR-TBT cells.

Exposing the cells to nitric oxide donor induced a reduction of taurine uptake significantly in TR-TBT cells (Table 2). NO donor, SIN-1, releases $\mathrm{NO}, \mathrm{O}_{2}{ }^{-}$and
$\mathrm{ONOO}^{-}$. It was demonstrated that $\mathrm{ONOO}^{-}$interacted with TauT tyrosine residues and formation of nitrotyrosine was detected highly in NO donor treatment [29-32]. These alterations of transporter induced a reduction of taurine transport activity. In pregnant women having intrauterine growth restriction (IUGR) disease, placental transport capacity of taurine was reduced and fetal taurine level was decreased [33]. In addition, it has been previously shown that IUGR is associated with increased fetoplacental NO levels [12]. Thus, NO could play an important role in down-regulating TauT activity in IUGR.

Taurine efflux in TR-TBT cells was examined by measuring the remaining intracellular taurine. Our results showed that $\left[{ }^{3} \mathrm{H}\right]$ taurine efflux was significantly decreased by TNF- $\alpha$ pre-treatment, but had no change by LPS and DEM (Fig. 3). These results coincided with previous in vivo study in rat brain [34]. Thus, oxidative stress condition affected taurine efflux in TR-TBT cells as well as taurine uptake. Also, these results suggested that decrease of taurine efflux by TNF- $\alpha$ may be a possible mechanism for increase of taurine uptake to the cells.

\section{Conclusions}

1. Taurine transport was regulated by PKC in TRTBT cells. Also, $\mathrm{Ca}^{2+}$ was involved in taurine transport, and $\mathrm{Ca}^{2+}$ free conditions decreased taurine uptake and evoked taurine efflux.

2. Oxidative stress induced the change of taurine transport in TR-TBT cells, but the change was different as a type of oxidative stress inducing agents. Taurine uptake was increased by TNF- $\alpha$, LPS and DEM pre-treatment, but decreased by $\mathrm{H}_{2} \mathrm{O}_{2}$ and $\mathrm{NO}$ stimulation. Whereas, taurine efflux was only regulated by TNF- $\alpha$ pre-treatment.

3 . The taurine transport through the BPB was regulated in various stress conditions, and these results suggest that variable stresses affect the taurine supplies from maternal blood to fetus and taurine level of fetus.

\section{Acknowledgements}

This article has been published as part of Journal of Biomedical Science Volume 17 Supplement 1, 2010: Proceedings of the 17th International Meeting of Taurine. The full contents of the supplement are available online at http://www.jbiomedsci.com/supplements/17/S1.

This study was supported in a grant from the SRC Research Center for Women's Diseases of Sookmyung Women's University.

\section{Authors' contributions}

Lee NY carried out the functional study, the experiments and helped to draft the manuscript. Kang YS participated in the data analysis and design of the study, and drafted the manuscript. All authors read and approved the final manuscript.

Competing interests

The authors declare that they have no competing interests. 
Published: 24 August 2010

\section{References}

1. Huxtable RJ: Physiological actions of taurine. Physiol Rev 1992, 72:101-163.

2. Tappaz ML: Taurine biosynthetic enzymes and taurine transporter: molecular identification and regulations. Neurochem Res 2004, 29:83-96.

3. Lambert $\mathrm{IH}$ : Regulation of the cellular content of the organic osmolyte taurine in mammalian cells. Neurochem Res 2004, 29:27-63.

4. Foos TM, Wu JY: The role of taurine in the central nervous system and the modulation of intracellular calcium homeostasis. Neurochem Res 2002, 27:21-26.

5. Chapman GE, Greenwood CE: Taurine in nutrition and brain development. Nutr Res 1988, 8:955-968.

6. Sturman JA: Taurine in development. J Nutr 1988, 118:1169-1176

7. Jansson T: Amino acid transporters in the human placenta. Pediatr Res 2001, 49:141-147.

8. Kulanthaivel P, Cool DR, Ramamoorthy S, Mahesh VB, Leibach FH, Ganapathy V: Transport of taurine and its regulation by protein kinase $C$ in the JAR human placental choriocarcinoma cell line. Biochem J 1991, 277:53-58.

9. Ramamoorthy S, Leibach FH, Mahesh VB, Han H, Yang-Feng T, Blakely RD, Ganapathy V: Functional characterization and chromosomal localization of a cloned taurine transporter from human placenta. Biochem J 1994, 300 $893-900$

10. Norberg $\mathrm{S}$, Powell $\mathrm{TL}$, Jansson $\mathrm{T}$ : Intrauterine growth restriction is associated with a reduced activity of placental taurine transporters. Pediatr Res 1998, 44:233-238.

11. Lyall F, Greer I, Young A, Myatt L: Nitric oxide concentrations are increased in the feto-placental circulation in intrauterine growth restriction. Placenta 1996, 17:165-168.

12. Rubin E: Essential Pathology. Maryland: Lippincott Williams\&Wilkins 2001.

13. Kitano $T$, lizasa $H$, Terasaki $T$, Asashima $T$, Matsunaga $N$, Utoguchi $N$, Watanabe Y, Obinata M, Ueda M, Nakashima E: Polarized glucose transporters and mRNA expression properties in newly developed rat syncytiotrophoblast cell lines, TR-TBTs. J Cell Physiol 2002, 193:208-218.

14. Kitano T, lizasa H, Hwang IW, Hirose Y, Morita T, Maeda T, Nakashima E: Conditionally immortalized syncytiotrophoblast cell lines as new tools for study of the blood-placenta barrier. Biol Pharm Bull 2004, 27:753-759.

15. Lee NY, Choi HM, Kang YS: Choline transport via choline transporter-like protein 1 in conditionally immortalized rat syncytiotrophoblast cell lines TR-TBT. Placenta 2009, 30:368-374.

16. Mochizuki T, Satsu H, Shimizu M: Signaling pathways involved in tumor necrosis factor $\alpha$-induced upregulation of the taurine transporter in Caco-2 cells. FEBS Letters 2005, 579:3069-3074

17. Molchanova SM, Oja SS, Saransaari P: Mechanisms of enhanced taurine release under $\mathrm{Ca}^{2+}$ depletion. Neurochem Int 2005, 47:343-349.

18. Kang YS, Ohtsuki S, Takanaga H, Tomi M, Hosoya KI, Terasaki T: Regulation of taurine transport at the blood-brain barrier by tumor necrosis factor$\alpha$, taurine and hypertonicity. J Neurochem 2002, 83:1188-1195.

19. Chang RCC, Stadlin A, Tsang D: Effects of tumor necrosis factor alpha on taurine uptake in cultured rat astrocytes. Neurochem Int 2001, 38:249-254.

20. Han X, Budreau AM, Chesney RW: Cloning and characterization of the promoter region of the rat taurine transporter (TauT) gene. Adv Exp Med Biol 2000, 483:97-108.

21. Bannai S: Induction of cystine and glutamate transport activity in human fibroblast by diethyl maleate and other electrophilic agents. J Biol Chem 1984, 259:2435-2440

22. Hosoya Kl, Saeki S, Terasaki T: Activation of carrier-mediated transport of $\mathrm{L}$-cystine at the blood-brain and blood-retinal barriers in vivo. Microvas Res 2001, 62:136-142.

23. Kim HW, Kim JH, An HS, Park KK, Kim BK, Park T: Myo-inositol restores the inflammation-induced down-regulation of taurine transport by the murine macrophage cell line, RAW 264.7. Life Sci 2003, 73:2477-2489.

24. Romio L, Zegarra-Moran, Varesio L, Galietta LJV: Regulation of taurine transport in murine macrophages. Amino Acids 2001, 21:151-160.

25. O'Flaherty L, Stapleton PP, Redmond HP, Bouchier-Hayes D: Dexamethasone and lipopolysaccharide regulation of taurine transport in Caco-2 cells. J Surg Res 1997, 69:331-336.

26. Meng TC, Fukada T, Tonks NK: Reversible oxidation and inactivation of protein tyrosine phosphatases in vivo. Mol Cell 2002, 9:387-399.
27. Voss JW, Pedersen SF, Christensen ST, Lambert IH: Regulation of the expression and subcellular localization of the taurine transporter TauT in mouse NIH3T3 fibroblasts. Eur J Biochem 2004, 271:4646-4658.

28. Kazanietz MG, Areces LB, Bahador A, Mischak H, Goodnight J, Mushinski JF, Blumberg PM: Characterization of ligand and substrate specificity for the calcium-dependent and calcium-independent protein kinase $C$ isozymes. Mol Pharmacol 1993, 44:298-307.

29. Kulanthaivel P, Leibach FH, Mahesh VB, Ganapathy V: Tyrosine residues are essential for the activity of the human placental taurine transporter. Biochem Biophys Acta 1989, 985:139-146.

30. Myatt L, Rosenfield RB, Eis AL, Brockman DE, Greer I, Lyall F: Nitrotyrosine residues in placenta. Evidence of peroxynitrite formation and action. Hypertension 1996, 28:488-493.

31. Roggensack AM, Zhang Y, Davidge ST: Evidence for peroxynitrite formation in the vasculature of women with preclampsia. Hypertension 1999, 33:83-89.

32. Khullar S, Greenwood SL, Mccord N, Glazier JD, Ayuk PTY: Nitric oxide and superoxide impair human placental amino acid uptake and increase $\mathrm{Na}^{+}$ permeability: implications for fetal growth. Free Radic Biol Med 2004, 36:271-277.

33. Roos $\mathrm{S}$, Powell $T L$, Jansson $\mathrm{T}$ : Human placental taurine transporter in uncomplicated and IUGR pregnancies: cellular localization, protein expression, and regulation. Am J Physiol Regul Integr Comp Physiol 2004, 287:R886-R893.

34. Lee NY, Kang YS: The brain-to-blood efflux transport of taurine and changes in the blood-brain barrier transport system by tumor necrosis factor- $\alpha$. Brain Res 2004, 1023:141-147.

doi:10.1186/1423-0127-17-S1-S37

Cite this article as: Lee and Kang: Regulation of taurine transport at the blood-placental barrier by calcium ion, PKC activator and oxidative stress conditions. Journal of Biomedical Science 2010 17(Suppl 1):S37.

\section{Submit your next manuscript to BioMed Central and take full advantage of:}

- Convenient online submission

- Thorough peer review

- No space constraints or color figure charges

- Immediate publication on acceptance

- Inclusion in PubMed, CAS, Scopus and Google Scholar

- Research which is freely available for redistribution 